\title{
MEKANISME PEMBIAYAAN KPR IB BERDASARKAN AKAD MURABAHAH DI PERBANKAN SYARIAH
}

\author{
Mahfudz \\ Pondok Pesantren Tahfidzul Qur'an Wushulul Fawwaz \\ mahfudz_elkuweisy@yahoo.com
}

\begin{abstract}
Abstrak
Dalam penulisan artikel ini penulis akan mengungkap dan menerangkan tentang prosedur dan mekhganisme pembiayaan KPR IB berdasarkan akad murabahah pada Bank BRI Syariah Kendari. Adapun rujukan yang digunakan adalah Al-Qur'an, hadis serta fatwa DSN-MUI. Berdsarkan hasil penelitian, Bank BRI Syariah Kendari dalam menerapkan pembiayaan KPR IB belum sepenuhnya sesuai hukum syariah, khususnya terkait uang muka/DP dan penjaminan rumah yang melibatkan pihak lain.
\end{abstract}

Kata Kunci: Mekanisme Pembiayaan Kpr Ib, Akad Murabahah, Perbankan Syariah

\section{الملخص}

في خلال هذا البحث ستبين وستوضح الباحث عن عملية التمويل لتمليك السكن البنك

الإسلامي بناء علي عقد المرابحة في مصرف الإسلامي إندونيسيا فرع كينداري. ومع هذا، تصدر

البحث من القرآن، السنة والفتاوي الإقبصادي. و النتيجة هذا البحث من خلال ملاحظات تظهر علي

أن مصرف الإسلامي في تطبيق المعاملات المالية خصوصا في عقد المرابحة في تمليك السكن

يخالف عن الثريعة و الفتاوي الإسلامية خصوصا في الحامش جدية وكفالة السكن التي تربط فريق

Keywords: Mekanisme Pembiayaan Kpr Ib, Akad Murabahah, Perbankan Syariah 


\section{Pendahuluan}

Bank Syariah memiliki peran penting dan kontribusi dalam perkembangan ekonomi di Indonesia. Pada tahun 1998 ketika Indonesia dilanda krisis moneter BankBank Konvensional mengalami kerugian dan tidak bisa menghadapi krisis yang ada pada saat itu, Bank Syariah tetap berdiri kokoh memberikan pengaruh dan kontribusi ekonomi di Indonesia khususnya di sektor-sektor riil.

Bank Muamalat Indonesia lahir pada tahun 1991 sebelum diundangkannya Undang-Undang tentang perbankan yang baru, yaitu undang-undang No.7 Tahun 1992. Berdasarkan Undang-Undang No.7 Tahun 1992 itu, dimungkinkan bagi bank untuk melekukan kegiatan usahanya bukan berdasarkan bunga tetapi berdasarkan bagi hasil. Setelah Undang-Undang No.7 Tahun 1992 diubah dengan Undang-Undang No.10 Tahun 1998, secara tegas disebutkan dimungkinkannya pendirian bank berdasarkan Prinsip Syariah dan dimungkinkannya Bank Konvensional untuk memiliki Islamic Windows, dengan mendirikan unit usaha syariah. Sejak waktu itu, Indonesia menganut Dual Banking System, yaitu Sistem Perbankan Konvensional dan Sistem Perbankan Syariah. ${ }^{1}$

Dengan terbitnya UU No. 10 Tahun 1998 maka Bank BRI mendirikan Bank BRI Syariah, Berawal dari akuisisi PT. Bank Rakyat Indonesia (Persero), Tbk. terhadap Bank Jasa Arta pada 19 Desember 2007 dan setelah mendapatkan izin dari Bank Indonesia pada 16 Oktober 2008 melalui suratnya dengan Nomor o.10/67/KEP.GBI/DpG/2008, maka pada tanggal 17 November 2008 PT. Bank BRI Syariah secara resmi beroperasi. ${ }^{2}$

\footnotetext{
${ }^{1}$ Sutan Remy Sjahdeini, Perbankan Syariah Produk-Produk dan Aspek-Aspek Hukumnya, Jakarta, Kencana Prenadamedia Group, 2014, h 97

${ }^{2}$ www.BRIsyariah.co.id, Diakses Pada Tanggal 31 Mei 2018
} 
Tak heran jika perkembangan Perbankan Syariah cukup pesat. Dalam kurun waktu 15 tahun Perbankan Syariah secara keseluruhan terdiri dari 3 Bank Umum Syariah, 25 Unit Usaha Syariah 109 Bank Perkreditan Rakyat Syariah (BPRS). ${ }^{3}$

Perbankan Syariah di Indonesia mengalami perkembangan dengan pesat, walaupun sebagian masyarakat masih ada yang berasumsi bahwa Bank Syariah hanyalah sebuah label yang digunakan untuk menarik simpati masyarakat Muslim dibidang perbankan. Mereka berpendapat bahwa Bank Syariah merupakan Bank Konvensional yang hanya dibubuhi Bismillâhirramânirrahîm dan pegawai yang mengenakan busana Islami dan mengucap Salam, akan tetapi dalam pelaksanaan akad pada Bank Syariah masih terkontaminasi dengan sistem-sistem yang tidak dilegalkan oleh Syariah.

Sikap skeptis dari masayarakat tentang Perbankan Syariah tersebut tidak dapat dipungkiri karena konotasi perbankan sejak dahulu memang terpisah secara nyata dengan syariah, sehingga pada awalmula pembentukan Perbankan Syariah banyak yang tidak percaya akan adanya keberhasilan para Ekonom Islam dalam menyatukan Institusi perbankan dengan syariah. ${ }^{4}$

Kalangan ulama fikih keabsahan pembiayaan murabahah masih menjadi perbedaan. Ada sebagian ulama yang membolehkan karena murabahah merupakan jual beli, tetapi ada sebagian ulama yang melarang karena beranggapan bahwa murabahah itu bukanlah jual beli melainkan hilah untuk mendapatkan riba. Ada sebagian ulama yang menganggapnya sebagai bai' al-inah yang haram hukumnya, dan ada sebagian ulama

\footnotetext{
${ }^{3}$ Anita Rahmawati, Ekonomi Syariah: Tinjauan Kritis Produk Murabahah Dalam Perbankan Syariah di Indonesia, Jurnal Ekonomi Islam La-Riba, Vol. I No.2, Desember 2007, h.187

${ }^{4}$ Bagya Agung Prabowo, Konsep Akad Murabahah Pada Perbankan Syariah (Analisis Kritis Terhadap Aplikasi Konsep Akad Murabahah di Indonesia dan di Malaysia, jurnal hukum No.1 Vol. 16 Januari 2009, h. 107-108
} 
yang menganggapnya sebagai bai' al-ma'dum, ada pula yang menganggapnya bai'ataini fî al-bai'ah. ${ }^{5}$

Berangkat dari tulisan diatas penulis akan akan menguraikan konsep murabahah yang sesuai syariah, dan mengulas implementasi pembiayaan KPR IB berdasarkan akad murabahah pada perbankan syariah.

\section{Pengertian Bank Syariah}

Kata Bank dapat kita telusuri dari kata Banque dalam bahasa Prancis, dan dari Banco dalam bahasa Italia, yang dapat berarti peti/lemari atau bangku. Konotasi kedua kata ini menjelaskan dua fungsi dasar yang di tunjukkan oleh Bank Komersial. Kata peti atau lemari menyiratkan fungsi sebagai tempat penyimpanan benda-benda berharga, seperti peti emas, peti berlian, peti uang, dan sebagainya. Dewasa ini peti bank berarti portepel aktiva yang menghasilkan (portofolio of earning assets), yaitu portofolio yang memberi bank "darah kehidupan” bernama laba bersih setelah pengeluaran-pengeluaran dan pajak. ${ }^{6}$

Pengertian bank menurut Undang-Undang Nomor 21 Tahun 2008 yaitu: "bank adalah badan usaha yang menghimpun dana dari masyarakat dalam bentuk simpanan dan menyalurkannya kepada masyarakat dalam bentuk kredit dan/atau bentuk lainnya dalam rangka meningkatkan taraf hidup rakyat". ${ }^{7}$

5 Anita Rahmawati, "Ekonomi Syariah: tinjauan kritis produk murabahah dalam perbankan syariah di Indonesia”, ,.., h.188-189

6 Zainul Arifin, Dasar-Dasar Manajemen Bank Syariah, (Cet ke tujuh, Tangerang, Azkia Publishar, 2009), h. 2

${ }^{7}$ Muslimin Kara, Kontribusi Pembiayaan Perbankan Syariah Terhadap Pengembangan Usaha Mikro, Kecil, dan Menengah, Ahkam Jurnal Ilmu Syariah, Vol 13 No.2 Juli 2013, h. 315 
Bank Islam atau selanjutnya disebut dengan Bank Syariah, adalah bank yang beroperasi dengan tidak mengandalkan pada bunga. Bank Islam atau bisa disebut bank tanpa bunga, adalah lembaga keuangan/perbankan yang operasional dan produknya dikembangkan berdasarkan pada al-Qur'an dan hadis Nabi Saw. Atau dengan kata lain, Bank Islam adalah lembaga keuangan yang usaha pokoknya memberikan pembiayaan dan jasa-jasa lainnya dalam lalulintas pembayaran serta peredaran uang yang pengoperasiannya disesuaikan dengan prinsip syariat Islam. ${ }^{8}$

\section{Pembiayaan Murabahah}

1. Pengertian Murabahah

Murabahah secara bahasa diambil dari kata rabaha, yang berarti tumbuh atau berkembang dalam perdagangan atau jual beli. Sedangkan secara istilah para ulama berbeda pandangan tentang pengertian murabahah diantaranya sebagai berikut: ${ }^{9}$

1) Menurut imam al-Marginani al-Hanafi, murabahah yaitu memindahkan sesuatu yang dimilikinya dengan akad yang pertama dan harga yang pertama dengan adanya tambahan keuntungan.

2) Ibnu Rusyd al- Maliki; Penjual menyebutkan harga/modal barang yang telah ia beli kemudian mensyaratkan adanya keuntungan dari barang tersebut baik itu dari dirham atau dinar.

3) Syekh Abu Ishak as- Syairaszi as-Syafii; Penjual mejelaskan harga/modal asli barang dan memberitahukan perkiraan keuntungan dari barang tersebut seperti ketika penjual mengatakan bahwa harga barang ini seratus dirham dan saya akan menjual barang ini kepadamu sesuai dengan harga/modalnya dan akan mengambil keuntungan satu dinar setiap sepuluh dinar dari modal.

${ }^{8}$ Muhammad, Manajemen Dana Bank Syariah, Jakarta, PT Rajagrafindo Persada, 2014, h. 2

Lihat : Muhammad, Sistem Bagi Hasil dan Princing Bank Syariah, (Cet pertama, Yogyakarta,UII Press, 2016), h.1

${ }^{9}$ Hisyam ad-Din Musa A'fanah,(Bai' al-Murabahah Lil Amir bi Syira, Cetakan ke 1, tk), h. 1214. 
4) Syekh Ibnu Qudamah al-Maqdisi al-Hanbali Menjual barang sesuai dengan harganya dan dengan jumlah keuntungan yang diketahui.

Dari penjelasan diatas tentang pengertaian murabahah maka bisa kita simpulkan sebagai berikut, murabahah adalah menjual suatu barang sesuai dengan harga awal dengan adanya keuntungan yang diketahui dan telah disepakati kedua belah pihak.

2. Rukun dan Syarat Murabahah.

Rukun murabahah pada dasarnya sama dengan rukun jual beli biasa, seperti adanya penjual, ada pembeli dan barang yang menjadi objek transaksi. Adapun syarat murabahah adalah sebagai berikut: ${ }^{10}$

1) Harga pokok awal suatu barang harus diketahui, artinya disyaratkan harga pokok suatu barang harus diketahui oleh pembeli yang kedua, karena mengetahui harga suatu barang merupakan syarat sahnya jual beli, sehingga jika harga pokok suatu barang tidak diketahui maka jual beli menjadi fasid.

2) Keuntungan harus diketahui, artinya keuntungan dalam jual beli harus diketahui karena keuntungan termasuk dalam harga jual suatu barang dan mengetahui harga adalah syarat sahnya jual beli.

3) Modal harus berupa barang misliyat (artinya harga barang tersebut harus bisa di ukur, ditimbang atau dihitung) dan sesuatu barang yang nilainya dapat diketahui seperti dinar dan dirham.

4) Tidak diperbolehkan melakukan jual beli murabahah terhadap barang-barang ribawi dan adanya riba pada harga barang yang petama, seperti membeli barang yang dapat diukur, ditimbang dengan jenis yang sama maka tidak boleh menjualnya secara murabahah, karena pada hakikatnya murabahah adalah

\footnotetext{
${ }^{10}$ Wahbah az-Zuhaili, al-Fikh al-Islami wa Adillatuh, jilid ke empat, h. 704-706
} 
menjual barang dengan harga pokok ditambah dengan keuntungan. Tambahan dalam harta ribawi termasuk riba bukan keuntungan.

5) Akad yang pertama dilakukan dengan cara yang sah, jika akad pertamanya tidak sah maka tidak boleh dijual secara murabahah.

\section{Landasan Hukum Murabahah}

Para jumhur ulama telah sepakat tentang bolehnya dan disyariatkannya murabahah. Adapun dalil disyariatkannya murabahah sebagai berikut: ${ }^{11}$

QS.al-Baqarah: 275

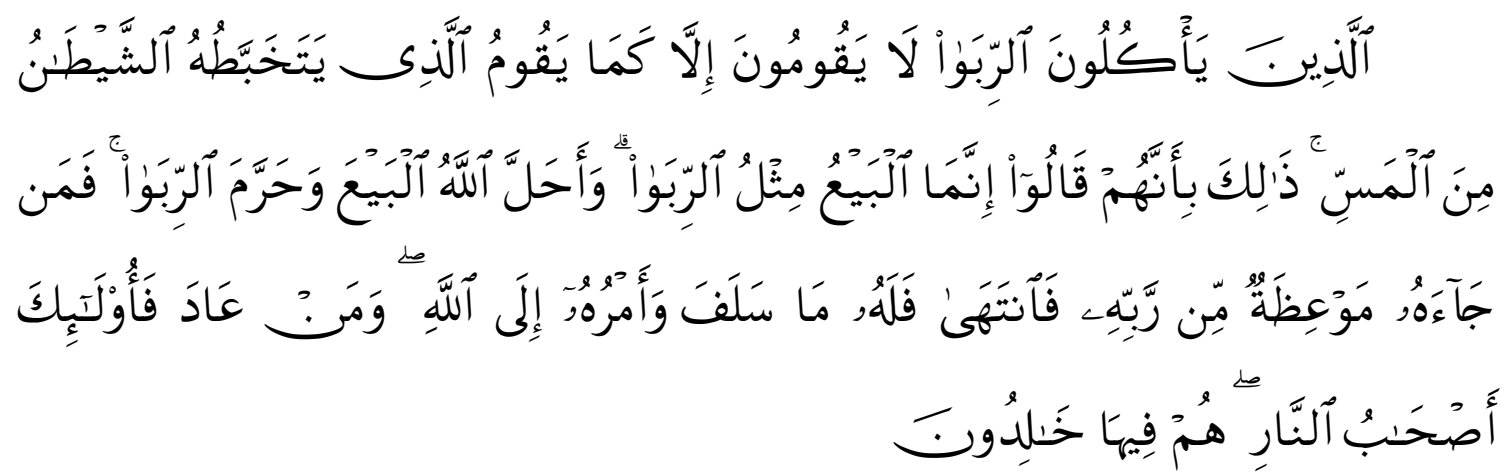

Terjemahnya:

"Orang-orang yang memakan riba tidak dapat berdiri melainkan seperti berdirinya orang yang kemasukan setan karena gila yang demikian itu karena mereka berkata bahwa jual beli itu sama dengan riba. padahal Allah Telah menghalalkan jual beli dan mengharamkan riba. Barang siapa mendapat pringatan dari Tuhannya, lalu dia berhenti, Maka apa yang Telah diperolehnya dahulu menjadi miliknya dan urusannya (terserah) kepada Allahbarang siapa mengulangi, Maka orang itu adalah penghuni-penghuni neraka, mereka kekal di dalamnya".12

QS. an-Nisa: 29

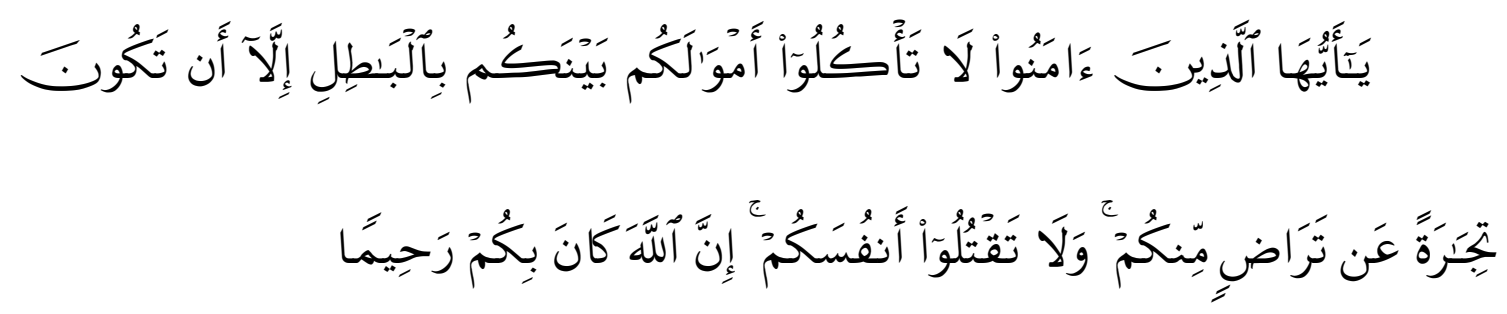

\footnotetext{
${ }^{11}$ Wuzaratu al-Auqaf wa Syuun al-Islami, al Mausua'tu al Fiqhiyah, juz ke-36, h. 318

12 Deraprtemen Agama RI, Al-Qur'an dan terjemahnya..., h. 47
} 


\section{Terjemahnya:}

"wahai orang-orang yang beriman! janganlah kamu saling memakan harta sesamamu dengan jalan yang batil (tidak benar), kecuali dalam perdagangan yang berlaku atas dasar suka sama-suka di antara kamu. dan janganlah kamu membunuh dirimu. Sesungguhnya Allah adalah Maha Penyayang kepadamu". ${ }^{3}$

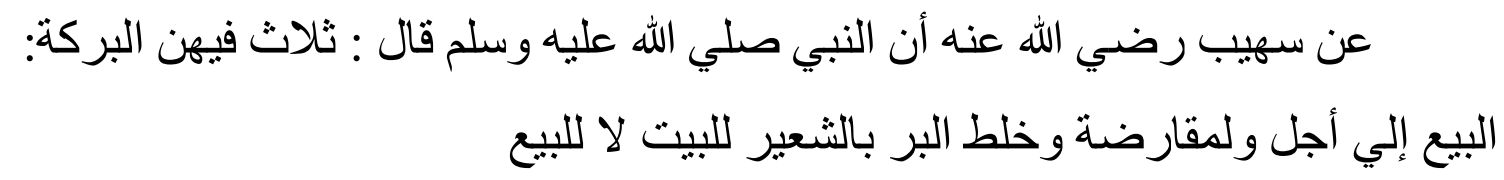

Artinya:

"Dari suhaib ar-Rumi r.a. bahwa Rasulullah saw. Bersabda, "tiga hal yang didalamnya terdapat keberkahan: jual beli secara tangguh, muqaradhah (mudharabah), dan mencampur gandum dengan tepung untuk keperluan rumah bukan untuk dijual.” (HR. Ibnu Majah dengan sanat dhaif'. ${ }^{\prime}$

\section{Aplikasi Konsep Murabahah Pada Perbankan Syariah di Indonesia}

Salah satu skim fikih yang paling populer yang diterapkan oleh perbankan syariah adalah skim jual beli murabahah. Murabahah dalam perbankan syariah didefinisikan sebagai jasa pembiayaan dengan mengambil bentuk transaksi jual beli barang antara bank dengan nasabah dengan cara pembayaran angsuran. Dalam perjanjian murabah, bank mebiayai pembelian barang atau asset yang dibutuhkan oleh nasabahnya kepada nasabah tersebut dengan menambahkan suatu mark-up atau margin keuntungan. Dengan kata lain, penjualan barang oleh bank kepada nasabah dilakukan atas dasar cost-plus profit. ${ }^{15}$

Murabahah sebagaiman ditetapkan dalam perbankan syariah, pada prinsipnya didasarkan pada dua elemen pokok, yaitu harga beli serta biaya yang terkait dan

${ }^{13}$ Deraprtemen Agama RI, Al-Qur'an dan terjemahnya..., h. 83

${ }^{14}$ Al-Hafidz Abi Abdullah Muhammad bin Yazid al-Qazwaini, Sunan Ibnu Majjah, Dâr Ihya alQutub al-Arabiyah, 275M, Juz I, Hadis No. 2289, Hal 768.

15 Anita Rahmawati, “Ekonomi Syariah: Tinjauan Kritis Produk Murabahah Dalam Perbankan Syariah di Indonesia,” Jurnal la_Riba, Vol. I, Desember 2007, h. 191 
kesepakatan atas mark-up. Ciri dasar kontrak pembiayaan murabahah adalah sebagai berikut: ${ }^{16}$

1. Pembeli harus memiliki pengetahuan tentang biaya-biaya terkait dan harga pokok barang dan batas mark-up harus ditetapkan dalam bentuk presentase dari total harga plus biaya-biayanya.

2. Apa yang dijual adalah barang atau komoditas dan dibayar dengan uang.

3. Apa yang diperjual belikan harus ada dan dimiliki oleh penjual dan penjual harus mampu menyerahkan barang itu kepada pembeli.

4. Pembayaran ditangguhkan

Bank Syariah di Indonesia pada umumnya dalam memberikan pembiayaan murabahah, menetapkan syarat-syarat yang dibutuhkan dan prosedur yang harus ditempuh oleh musytari yang hampir sama dengan syarat dan prosedur kredit sebagaimana lazimnya yang ditetapkan oleh Bank Konvensional. Syarat dan ketentuan umum pembiayaan murabahah yaitu: Umum, tidak hanya diperuntukkan untuk kaum muslimin saja; harus cakap hukum, sesuai dengan KUHPerdata; memenuhi 5C yaitu: character (watak); collateral (jaminan); capital (modal); condition of economy (prospek usaha); capability (kemampuan).

Memenuhi kebutuhan Bank Indonesia dan pemerintah, sesuai yang diatur Undang-Undang No. 10 Tahun 1998 tentang perubahan Undang-Undang No. 7 Tahun 1992 tentang perbankan; jaminan (dhamman), biasanya cukup dengan barang yang dijadikan obyek perjanjian namun kerena besarnya pembiayaan lebih besar dari harga

\footnotetext{
${ }^{16}$ Anita Rahmawati, “Ekonomi Syariah ..., h. 191-192
} 
pokok barang (karena ada mark up) maka pihak bank mengenakan uang muka senilai kelebihan jumlah pembiayaan yang tidak tertutup oleh harga pokok barang

Pembiayaan murabahah yang dilakukan oleh bai' dan musytari dalah perjanian jual beli, jika seseorang datang kepada bank syariah dan ingin meminjam dana untuk membeli barang tertentu, misalnya mobil atau rumah, suka atau tidak suka ia harus melakukan jual beli dengan bank sariah, bank syariah bertindak sebagai bai' dan nasabah sebagai musytari, begitulah cara dari bank untuk memperoleh manfaat (keuntungan) yaitu dari laba penjualan atas barang bukan dari kelebihan yang disyaratkan dalam perjanjian pinjam meminjam karena bagaimanapun juga bank syariah sebagai lembaga komersial pasti ingin mendapatkan keuntungan. Keuntungan yang didapatkan dari pihak bai' adalah mark up (laba) dari penjualan barang dalam pembiayaan murabahah. ${ }^{17}$

Praktik yang sering terjadi, pihak bank syariah tidak selalu murni sebagai penjual barang seperti industry penjual barang yang menjual barang secara langsung kepada pembeli. Akan tetapi bank juga bisa mewakilkan pembelian barang kepada nasabah disertai dengan surat kuasa dari bank, setelah nasabah membayar barang yang dibeli maka nasabah kembali kepada bank dengan membawa bukti pembelian berupa nota ataupun faktur.

${ }^{17}$ Bagya Agung Prabowo, Konsep Akad Murabahah Pada Perbankan Syariah (Analisis Kritis Terhadap Aplikasi Konsep Akad Murabahah di Indonesia Dan Malaysia), Journal Hukum, No.1, Vol. 16, Januari 2009, h. 111-112 
Sekma Pembiayaan Murabahah

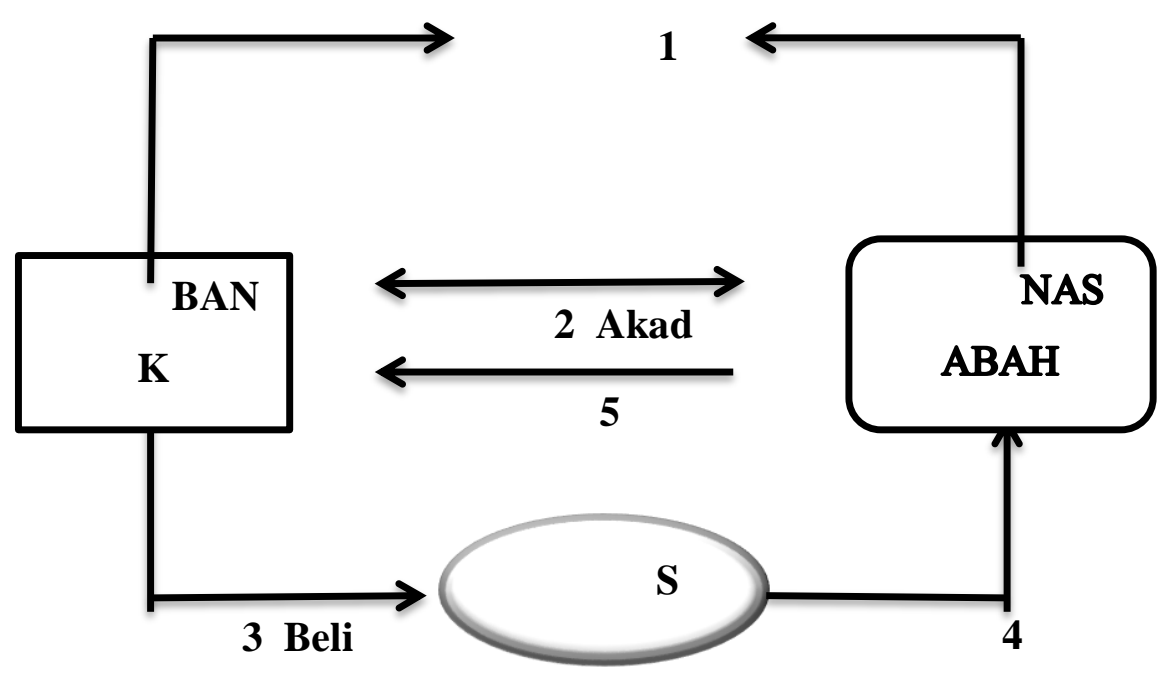

Bagan pembiayaan murabahah melalui wakalah

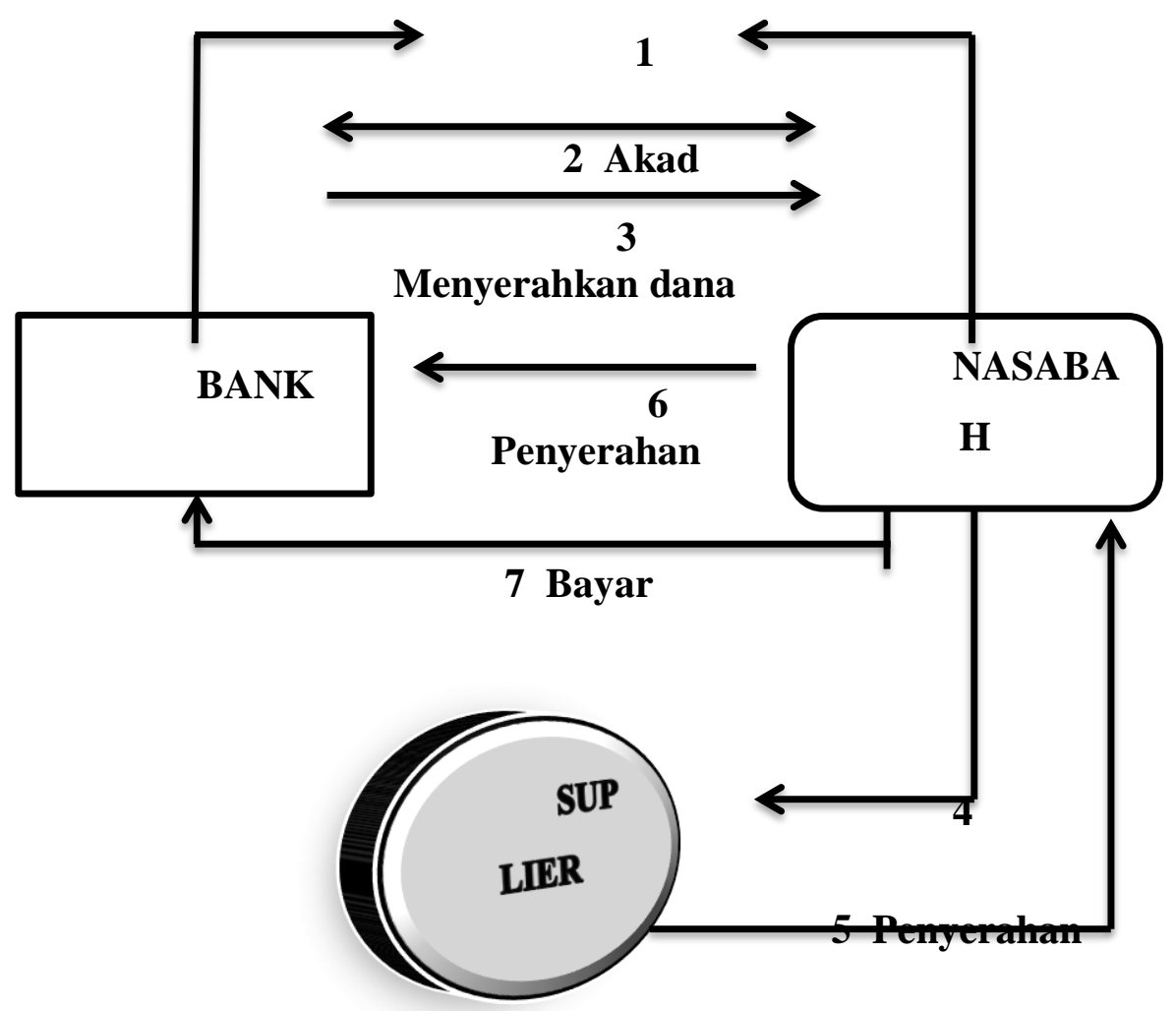




\section{Penerapan Akad Dalam Pembiayaan KPR IB}

Penerapan akad pembiayaan KPR IB, di dalamnya terdapat dua akad atu akad paralel yaitu akad wakalah dan akad murabahah, biasanya nasabah dan bank akan melakukan akad wakalah terlebih dahulu kemudian akad murabahah. Sebagaimana wawancara kami engan salah seorang marketing Bank BRI Syariah Kendari. Nasabah, bank dan developer duduk bersama untuk akad, akad dilakukan dengan penandatanganan akad wakalah Kemudian dilakukan akad jual beli dan yang terakhir akad murabahah antara bank ke nasabah.

Adapun penggabungan akad dalam satu transaksi jumhur ulama membolehkan penggabungan akad dengan syarat jika akad tersebut dipisah merupakan akad yang sah bukan akad yang dilarang oleh syariat, diantara yang memolehkan penggabungan akad/hybrid contract adalah Ibnu al-Qayyim, Ibnu Taimiyah, Jumhur ulama Hanafiyah, Syafii, dan Hambali. Dianara dalail mereka yang membolehkan adalah karena Asal dari akad dan syarat adalah boleh, kecuali telah dibatalkan dan dilarang oleh syariah. Semua yang belum dilarang oleh Allah dan Rasulnya dari akad dan syarat tidak boleh mengharamkannya. ${ }^{18}$

\section{Uang Muka/ Down Payment (DP) Dalam Pembiayaan KPR Syariah pada Bank BRI Syariah Cabang Kendari}

Dalam mengajukan pembiayaan KPR Syariah terapat DP (down payment) atau disebut juga dengan uang muka sebagaimana yang diungkapkan oleh salah satu marketing Bank BRI Syariah.

"ketentuan DP (down payment) diatur oleh peraturan Bank Indonesia secara umum kemudian diatur oleh ketentuan internal BRI Syariah secara khusus. Besaran DP menyesuaikan dengan jenis pembiayaan. Fungsi DP adalah agar memunculkan rasa

${ }^{18}$ Nazih Hammad, Al-Uqud al-Murakkabah fil-fikhi al-Islami, Damaskus, 2011, Dar al-Qalam, h. 
memiliki dari yang membeli rumah tersebut. dan DP sudah termasuk dari bagian harga rumah." 19

Uang muka dalam pandangan fikih bermacam-macam pandangan para fukha, ada yang memandang uang muka sebagi $U^{\prime} r b u n^{20}$, ada juga yang melihat uang muka seperti Hamish jiddiyah. ${ }^{21}$ Jika uang muka kita artikan sebagai u'rbun maka mayoritas ulama melarang jual beli urbun. ${ }^{22}$ dengan alasan jual beli u'rbun merugikan salahsatu pihak dan tidak sesuai dengan ajaransyariah. Sedangkan fatwa DSN-MUI memolehkan perbankan untuk meminta uang muka pada nasabah bila kedua belah pihak telah sepakat.

Selain DSN-MUI beberapa buku fikih juga menjelaskan tentang uang muka. Dalam kitab al-mi'yar as-syari' dikatan bahwa: ${ }^{23}$ Diperbolehkan bagi bank untuk meminta uang muka yang disebut sebagai hamysh jiddiyah kepada nasabah yang kemudian dibayar oleh nasabah untuk memastikan keseriusannya dalam melakukan akad di perbankan, dan juga untuk menghindari adanya penipuan dan atau saling merugikan antara kedua belah pihak.

Jika kita perhatikan penuturan dari pihak bank diatas maka seolah-olah tidak ada masalah dengan uang muka, dimana nasabah membayar uang muka ke bank kemudian melakukan transaksi akad murabahah, akan tetapi faktanya dilapangan bukan seperti itu,

${ }^{19}$ Wawancara marketing BRI Syariah Cabang Kendari, 25 April 2018, Mandonga Kota Kendari

${ }^{20}$ U'rbun adalah membeli atau menyewa sesuatu kemuadian membayar penjual atau yang menyewakan sebagian dari harga barang, jika jual beli atau sewa menyewa telah sesuai maka $u$ 'rbun termasuk bagian dari harga barang. Akan tetapi jika transaksi tidak selesai maka u'rbun menjadi milik penjual atau yang menyewakan barang.

${ }^{21}$ Tanda keseriusan naabah dalam melakukan transaksi.

${ }^{22}$ Rafiq Yunus Mashri, Bai' al-U’rbun wa Ba'dhol Mustahdasati Fîhi, Dârul maktabi, Suriah, 2010, h. 7-11

${ }^{23}$ Al-mi'yar as-syari' (standar syariah Internasional AAOFI No 8 tentang al-murabahah lil amir bisy-syira, hal. 111 
dimana nasabah telah terlebih dahulu membayar uang muka/down payment (DP) kepada developer sebelum mengajukan berkas permohonan pembiayaan KPR Syariah ke bank. Hal ini diungkapkan oleh banyak nasabah, salah satunya dalah sebagai berikut.

“iyaa kalau DP kan kita bayarkan dulu ke developernya, baru kita mengajukan berkas ke bank kalau kita tidak membayar DP ke developer kita tidak bisa ke bank"24

Berdasarkan keterangan nasabah diatas, yang menyatakan bahwa uang muka disetorkan ke developer sebelum bertransaksi dengan bank, kalau kita lihat secara sekilas tidak bermasalah tetapi kalau kita teliti lebih dalam kita akan menemukan beberapa masalah didalamnya. Ada bebrapa masalah yang akan timbul dalam hal uang muka/DP: yang pertama, ketika nasabah membayar uang muka kepada developer maka ada dua kemungkinan status uang muka tersebut, apakah modal yang dibayar oleh nasabah ke developer adalah uang muka/DP ataukah sebagai penyertaan modal untuk membeli rumah. Jika uang yang dibayarkan nasabah ke developer adalah uang muka atau DP, maka sejatinya nasabah telah membeli rumah kepada developer. Karena dengan membayar DP atau uang muka kepada developer sebelum ke bank berarti nasabah telah dianggap membeli rumah kepada developer, terlepas lunas atau tidaknya pembayaran nasabah. Dengan demikian, kehadiran dan keterlibatan lembaga keuangan syariah (LKS) dalam pembiayaan rumah atau bank yang menawarkan KPR syariah hanyalah sebagai pemberi bantuan modal atau mengutangi kepada nasabah untuk menambahakan sisa modal yang dibutuhkan nasabah sekitar $80 \%$ sampai $90 \%$ untuk membeli rumah.

Jika demikian yang terjadi, kemudian bank mengambil keuntungan atau margin dari angsuran nasabah maka itu sama saja dengan praktek riba walaupun di bank itu

\footnotetext{
${ }^{24}$ Nasabah KPR Bank BRI Syariah Cabang Kendari inisial AS, Baruga 21 Juni 2018. Pukul 29.30
} 
dikatakan sebagai keuntungan. Kalaupun bank kemudian mengatakan telah menjual rumah tersebut kepada nasabah dengan harga angsuran, maka berarti bank telah menjual barang yang belum di miliki sepenuhnya karena nasabah telah terlebih dahulu memilikinya sebanyak 20\%, dalam hal ini agama melarang menjual barang yang tidak di miliki sepenuhnya. Sebagaimana syarat dalam jual beli, barang yang kita jual harus milkun tâm (kita miliki sepenuhnya) dan juga sabda rasulullah Saw yang melarang menjual barang yang belum kita miliki.

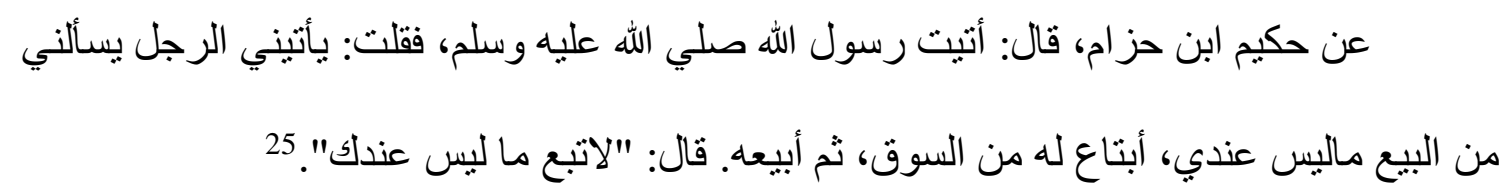

Artinya:

Dari Hakim Ibnu Hizam, berkata: saya datang kepada baginda Rasulullah Shallallahu Alaihi Wasallam, dan saya berkata: telah datang kepadaku seorang lelaki bertanya kepadaku tentang menjual barang yang belum saya miliki, yang saya jual di pasar, Rasulullah Saw. Bersabda: “jangan kamu menjual sesuatu yang bukan milikmu”.

\section{Potongan harga dalam akad murabahah}

Dalam perbankan syariah terdapat potongan harga bagi nasabah yang menyelesaiakan degan cepat angsurannya, akan tetapi potongan harga ini tidak diperjanjikan ketika akad melainkan hanya kebijkan bank. DSN-MUI membolehkan adanya potongan harga dengan syarat tidak diperjanjikan diawal akad.

25 Abi Isa Muhammad bin Isa bin Saurah, al-Jâmi' as-Shahih Sunan Tirmizi, Kairo, Maktaba Halabi, 209, Jilid 3, h. 525, Hadis No. 1232 


\section{Estimasi Angsuran KPR BRI Syariah ${ }^{26}$}

\begin{tabular}{|c|c|c|c|}
\hline $\begin{array}{c}\text { KPR } \\
\text { Murabahah }\end{array}$ & \multicolumn{3}{|c|}{ Jangka Waktu (Bulan) } \\
\hline Plafon & 60 & 120 & 180 \\
\hline 100.000 .000 & 2.249 .794 & 1.493 .107 & 1.314 .987 \\
\hline 250.000 .000 & 5.626 .485 & 3.732 .768 & 3.287 .468 \\
\hline 500.000 .000 & 11.248 .969 & 7.465 .537 & 6.574 .936 \\
\hline 750.000 .000 & 16.873 .454 & 11.198 .305 & 9.862 .405 \\
\hline 1.000 .000 .000 & 22.497 .938 & 14.931 .074 & 13.149 .873 \\
\hline
\end{tabular}

\section{Denda Keterlambatan Pembayaran Angsuran}

Jika nasabah yang memiliki kemampuan dalam melunasi angsurannya dibank tetapi dia sering menunda pembayarannya maka bank akan mengenakan denda keterlambatan pembayaran dengan terlebih dahulu memberikan surat peringatan berupa SP1 sampai SP3, jika sudah sampai SP3 nasabah belum juga melunasi angsurannya maka baiasanya akan dikenakan denda keterlambatan, tetapi denda ini hanya dikenakan kepada nasabah ynag memiliki kemampuan untuk membayarnya bukan nasabah yang sedang kesusahan finansial, dan uang hasil denda ini tidak boleh dimasukan sebagai pendapatan bank akan tetapi dimasukan kepada dana sosial.

\section{Jaminan Keamanan dan Keselamatan KPR BRI Syariah}

Dalam penjaminan keamanan dan keselematan rumah yang dimiliki nasabah, bank telah menjaminkan kepada pihak ketiga yaitu asuransi. Sehingga seolah-olah bank

\footnotetext{
${ }^{26}$ Bank BRI Syariah Cabang Kendari, Mandonga Kota Kendari, 27 April 2018, pukul 15.00
} 
tidak lagi menjamin keamanan dan keselamatan rumah yang diangsur oleh nasabah, sebagaimana yang dituturkan oleh salah satu nasabah Bank BRI Syariah. “ rumah kan sudah di jamin oleh asuransi". ${ }^{27}$

\section{Penutup}

Dalam praktreknya Bank BRI Syariah belum bisa dikatakan sepenuhnya murni syariah, karena msih ada akad yang belum sesuai dengan syariah dan juga masih bekerja sama dengan pihak-pihak atau lembaga konvensional. Disamping itu salah satu penyebab utama Bank Syariah belum bisa murni syariah adalah karena Bank Syariah masih mengikut dan terikat kepada Bank Indonesia sehingga Bank Syariah harus mengikuti semua regulasi yang diterapkan oleh Bank Indonesia.

\section{DAFTAR PUSAKA}

Abdillah Abi Muhammad bin Yazid al-Qazwaini as-syuhair, 1417 H, Sunan Ibnu Majah, al-Ma'arif, Riyadh

Ad-din Hisyam Musa A'fanah,(Bai' al-Murabahah Lil Amir bi Syira, Cet ke Satu.

Arifin Zainul, 2009, Dasar-Dasar Manajemen Bank Syariah, Cet ke tujuh, Azkia Publishar, Tangerang.

Az-Zuhaili Wahbah, 1984, al-Fikh al-Islami wa Adillatuh, Cet. Ke Tujuh, Dar al-Fikr, Lebanon.

Departemen Agama RI, 2009, al-Qura'an dan terjemahnya, PT. Sygma Examedia Arkanleema, Jakarta.

Hammad Nazih, 2011, al-Uqud al-murakkabah fil-fikhil islami, dar-alqalam, Damskus

Isa Abi Muhammad bin Isa bin Saurah, , al-Jâmi' as-Shahih Sunan Tirmizi, 209 H, Maktaba Halabi, Kairo.

Kara Muslimin, 2013, Kontribusi Pembiayaan Perbankan Syariah Terhadap Pengembangan Usaha Mikro, Kecil, dan Menengah, Ahkam Jurnal Ilmu Syariah, Vol 13 No.2

Muhammad, 2014, manajemen dana bank syariah, Cet. Pertama, PT Raja Grafindo, Jakarta.

\footnotetext{
${ }^{27}$ Wawancara dengan nasabah KPR BRI Syariah.
} 
2016, Sistem Bagi Hasil dan Princing Bank Syariah, Cet. Pertama, UII Press, Yogyakarta.

Prabowo Bagya Agung, 2009, Analisis Kritis Terhadap Aplikasi Konsep Akad Murabahah Di Indonesia dan Malaysia, Jurnal Hukum, (online) No. 1, Vol. 16, 107-108. https://media.neliti.com, diakses pada tanggal 11 Oktober 2017 pukul 10.00 .

Rahmawati Anita, 2007, Ekonomi Syariah: Tinjauan Kritis Produk Murabahah Dalam Perbankan Syariah di Indonesia, Jurnal La_Riba, (online) Vol. I No2, 187. http://Journal.uii.id, diakses pada tanggal 11 Oktober 2017 pukul 11.30.

Remi Sutan Sjahdeini, 2014, Perbankan syariah produk-produk dan aspek-aspek hukumnya, Kencana Prenadamedia Group, Jakarta.

Wuzaratu al-Auqaf wa Syuun al-Islami, al Mausua'tu al Fiqhiyah.

Yunus Rafiq Mashri, Bai' al-U'rbun wa mustahdasati fihi, 2010, Darul Maktabi, Suriah. www.BRIsyariah.co.id. 